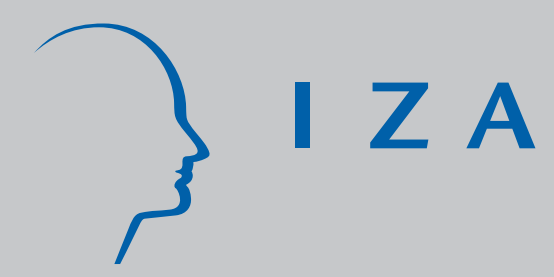

IZA DP No. 911

Are Nascent Entrepreneurs J acks-of-Al-Trades?

A Test of Lazear's Theory of Entrepreneurship with German Data

J oachim Wagner

October 2003 


\title{
Are Nascent Entrepreneurs Jacks-of- All-Trades? A Test of Lazear's Theory of Entrepreneurship with German Data
}

\author{
Joachim Wagner \\ University of Lueneburg, HWWA and IZA Bonn
}

\author{
Discussion Paper No. 911 \\ October 2003
}

\author{
IZA \\ P.O. Box 7240 \\ D-53072 Bonn \\ Germany \\ Tel.: +49-228-3894-0 \\ Fax: +49-228-3894-210 \\ Email: iza@iza.org
}

This Discussion Paper is issued within the framework of IZA's research area The Future of Labor. Any opinions expressed here are those of the author(s) and not those of the institute. Research disseminated by IZA may include views on policy, but the institute itself takes no institutional policy positions.

The Institute for the Study of Labor (IZA) in Bonn is a local and virtual international research center and a place of communication between science, politics and business. IZA is an independent, nonprofit limited liability company (Gesellschaft mit beschränkter Haftung) supported by Deutsche Post World Net. The center is associated with the University of Bonn and offers a stimulating research environment through its research networks, research support, and visitors and doctoral programs. IZA engages in (i) original and internationally competitive research in all fields of labor economics, (ii) development of policy concepts, and (iii) dissemination of research results and concepts to the interested public. The current research program deals with (1) mobility and flexibility of labor, (2) internationalization of labor markets, (3) welfare state and labor market, (4) labor markets in transition countries, (5) the future of labor, (6) evaluation of labor market policies and projects and (7) general labor economics.

IZA Discussion Papers often represent preliminary work and are circulated to encourage discussion. Citation of such a paper should account for its provisional character. A revised version may be available on the IZA website (www.iza.org) or directly from the author. 


\section{ABSTRACT}

\section{Are Nascent Entrepreneurs Jacks-of-All-Trades? A Test of Lazear's Theory of Entrepreneurship with German Data*}

In a recent paper Edward Lazear proposed the jack-of-all-trades view of entrepreneurship. Based on a coherent model of the choice between self-employment and paid employment he shows that having a background in a large number of different roles increases the probability of becoming an entrepreneur. The intuition behind this proposition is that entrepreneurs must have sufficient knowledge in a variety of areas to put together the many ingredients needed for survival and success in a business, while for paid employees it suffices and pays to be a specialist in the field demanded by the job taken. This paper contributes to the entrepreneurship literature by empirically testing Lazear's hypothesis using a large recent representative sample of the German population. The empirical estimation takes the rare events nature of becoming a nascent entrepreneur and the regional stratification of the sample into account. The results illustrate the statistical significance and economic importance of the jack-of-all-trades theory.

JEL Classification: J23, R12

Keywords: entrepreneurship, jack-of-all-trades theory, rare events logit, Germany

Joachim Wagner

University of Lueneburg

Institute of Economics

21332 Lueneburg

Germany

Email:wagner@uni-lueneburg.de

\footnotetext{
* Research for this paper was done as part of the project Regional Entrepreneurship Monitor (REM) Germany financially supported by the German Research Foundation under grants number WA 610/2-1 and WA 610/2-2. This project is conducted jointly with Rolf Sternberg (University of Cologne, Germany) who is supported with grants number STE 628/71 and STE 628/7-2.
} 


\section{Introduction}

In a recent paper that has the potential of becoming a pivotal element in the field Edward Lazear (2002) proposed the jack-ofall-trades theory of entrepreneurship. He uses a coherent model of the choice between self-employment and paid employment to show that having a background in a large number of different roles increases the probability of becoming an entrepreneur. The intuition behind this proposition is that entrepreneurs must have sufficient knowledge in a variety of areas to put together the many ingredients needed for survival and success in a business, while for paid employees it suffices and pays to be a specialist in the field demanded by the job taken. Lazear used a data set of Stanford alumni to test this prediction of his model and found it to hold - those with more varied experience have much higher probabilities of starting their own business.

Stanford alumni might not be representative for the millions of people facing the choice between self-employment and paid employment. This paper contributes to the entrepreneurship literature by empirically testing Lazear's jack-of-all-trades hypothesis using a large recent representative sample of the German population. It considerably extends and improves my earlier work on this topic reported in Wagner (2002) in three ways :

First, instead of using a ready-made data set that has been collected for different aims and, therefore, contains variables only that can at best be viewed as proxy variables for the concept central to Lazear's model - the number of professional 
fields a person has experience in - here a survey is used that includes a tailor-made question on this topic.

Second, instead of comparing self-employed and paid employees this paper focuses on the difference between nascent entrepreneurs - people who are in the process of starting their own business - and those who decide to continue working as paid employees. This should provide a much sharper test of Lazear's hypothesis because it makes sure that the reported number of fields of experience refers to a period that lies before the start of the own business.

Third, given that entrepreneurs tend to be a rare species (at least in Germany) application of the standard textbook logit or probit model is not appropriate when the decision to become an entrepreneur or not is modeled empirically. Therefore, a version of the logit model is used that takes care of the rare events nature of the decision to start one's own business.

The rest of the paper is organized as follows: Section 2 introduces the data used and presents descriptive statistics, section 3 discusses the results from the econometric investigation, and section 4 concludes.

\section{Data and descriptive statistics}

The data used in this paper are taken from a representative survey of the population aged 18 to 64 in 11 (out of 97) socalled planning regions in Germany that was conducted using computer assisted telephone interviewing by TNS EMNID, a leading opinion research institute, between June and August 2003. This survey is part of the research project Regional Entrepreneurship 
Monitor REM Germany 2003 which focuses on the extent of the difference in entrepreneurial activities between regions in Germany, its determinants, and its consequences for regional development. ${ }^{1}$ The questionnaire asked for socio-demographic characteristics (e.g., sex, age, employment status, education, fields of professional experience) and a number of items related to entrepreneurial activities (e. g., whether the interviewee is currently engaged in starting an own business). ${ }^{2}$

The data set contains information on 12.000 people. ${ }^{3}$ In the survey the interviewee was asked whether she/he is (alone or with others) actively involved in starting a new business that will (as a whole or in part) belong to her/him, and whether this business did not pay full time wages or salaries for more than three months to anybody (including the interviewee). Those who answered in the affirmative are considered to be nascent entrepreneurs. ${ }^{4}$ To test Lazear's jack-of-all-trades hypothesis

1 For further information about the REM project see Bergmann et al. (2002). REM is closely related to GEM, the Global Entrepreneurship Monitor, a multi-country study that investigates the same topics at a national level (see Reynolds et al. 2000).

2 An English version of the questionnaire is not yet available; a German version is available from the author on request.

3 The data will be made available for public scientific use after the completion of the REM project.

4 This definition of a nascent entrepreneur is identical to the definition used in the multi-country GEM project mentioned in footnote 1; see Reynolds et al. 2000, p.9. 
these nascent entrepreneurs are compared with paid employees who do not opt for a business of their own..$^{5}$

The variety of professional experience of an interviewee that is at the heart of Lazear's theory of entrepreneurship is measured by two variables:

- The survey includes a tailor-made question asking in how many different professional fields the interviewee has been active in the past, explaining that this does not mean the number of employers she/he worked for. The answer is included in the empirical investigation as the "number of fields of experience".

- The survey collects information about professional degrees completed after school, i.e. whether or not the interviewee successfully passed apprenticeship, managed to qualify formally as a master craftsperson, or received a degree from a polytech or university. The "number of professional degrees" (ranging from zero to three) is included as a variable in the empirical investigation.

5 As has been argued in the introduction, this approach instead of comparing self-employed and paid employees should provide a much sharper test of Lazear's hypothesis because it makes sure that the reported number of fields of experience refers to a period that lies before the start of the own business. In focusing on nascent entrepreneurs versus paid employees all other interviewees - including self-employed who are no nascents, and people out of the labor force like housewives, or those who are only marginally in the labor force by working part-time - have to be dropped from the sample used in the econometric investigation. 
Following Lazear (2002) we furthermore include sex and age in the empirical model. ${ }^{6}$

Means and standard deviations of these variables for nascent entrepreneurs and paid employees are reported in table I. The upper panel reports the values for an unrestricted sample. In the lower panel only persons are included that reported to have experience in up to 13 fields. The reason for this robustness check can be seen from a look at the frequency distribution of the answers to the question for the number of fields: While slightly above one in five of all respondents reported either one, or two or three fields, one in eight reported 4 fields, and one in ten 5 fields (so that 90 percent of all interviewees reported between 1 and 5 fields of experience), and 99 percent of all respondents mentioned up to 13 fields, the few remaining answered by reporting $15(\mathrm{~N}=21), 18(\mathrm{~N}=2), 20(\mathrm{~N}=21), 30(\mathrm{~N}=1)$, $43(\mathrm{~N}=1)$, and $50(\mathrm{~N}=2)$. Given that most of these numbers seem to be at best guesstimates, and that extreme values can have a large impact on the results from econometric investigation, a restricted sample was constructed limited to observations with 13 or less reported fields, and all computations were performed using this restricted sample, too.

[Table I near here]

From the upper panel of table I it can be seen that nascent entrepreneurs on average have one more field of experience and a

6 Note that contrary to both Lazear (2002) and Wagner (2002) nationality can not be included in the model used here because in the REM survey this information is not collected. 
slightly higher average value of number of professional degrees than paid employees. Furthermore, the proportion of men is higher among nascent entrepreneurs; and nascents are on average about two years younger. When we look at the results for the reduced sample reported in the lower panel we see that the difference between nascent entrepreneurs and paid employees in the number of fields of experience is much smaller now but still positive.

From the descriptive evidence reported in table I, therefore, we have some hints in favor of Lazear's jack-of-all-trades hypothesis.

\section{A test of the jack-of-all-trades hypothesis}

In the empirical model applied to test Lazear's jack-of-alltrades hypothesis the dummy variable indicating whether an individual is a nascent entrepreneur or not is regressed on a set of control variables (sex, age) and the two variables measuring the variety of professional experience of a person, viz. the number of different fields she/he has worked in, and the number of professional degrees she/he earned after completing school.

Starting a new business is a rare event; only 174 (or 3.5 percent) of all persons included in the unreduced sample are nascent entrepreneurs, and the respective figures for the reduced sample used in the robustness check are 168 ( or 3.4 percent). Application of standard textbook probit or logit methods to estimate the empirical models is not appropriate here. Gary King and Langche Zeng (2001a, 2001b) recently 
developed a version of the logit model to compute unbiased estimates in a situation like this. This method - labeled Rare Events Logistic Regression, or RELOGIT - is applied here. RELOGIT estimates the same logit model as the standard logit procedure, but uses an estimator that gives lower mean square error in the presence of rare events data for coefficients, probabilities, and other quantities of interest. Furthermore, to take the survey design into account and to allow that the observations might be dependent within a planning region, the variances of the estimated coefficients were estimated with the region as a cluster. ${ }^{7}$

[Table II near here]

Results based on the unrestricted sample are reported in column 1 of table II. To start with the control variables, the probability of being a nascent entrepreneur is higher for men, and it diminishes with an increasing age. According to the probvalues all the estimated coefficients are statistically different from zero at any conventional error level. Turning to the variables that are at the center of interest here, both the number of fields of experience and the number of professional degrees have a positive influence on the probability of being a nascent entrepreneur. These results which are highly significant

\footnotetext{
7 All computations were done with Stata 8.1 (see StataCorp 2003) using the relogit ado-file available from Gary King's homepage at Harvard <http://gking.harvard.edu>.
} 
statistically strongly support Lazear's jack-of-all-trades theory ${ }^{8}$

To check the robustness of these results the same model was estimated using a restricted sample were all observations are dropped that report a number of fields of experience larger than 13. From the results reported in column 2 of table II it can be seen that the big picture does not change.

Discussion of the results hitherto was limited to the statistical significance of the estimated coefficients and the direction of influence conducted by the variables. Information on the extent of this influence, or on the economic relevance, however, is even more important. Evidently, a variable that has no statistically significant impact can be ignored from an economic point of view, but the opposite is not true: A variable that is highly significant statistically might not matter at all economically - if the estimated probability for being a nascent entrepreneur increases by 0.00001 percentage points when an individual has experience in 5 instead of 2 fields the number of fields of experience can be ignored in the discussion of reasons for becoming a nascent entrepreneur irrespective of any high level of statistical significance indicated by the prob-value.

Unfortunately, the estimated coefficients from the rare events logit model can not easily be used for statements about the size of the ceteris paribus effect of a change on the value of an exogenous variable on the probability of being self-

8 To check for non-linear relationships an augmented model has been estimated that includes squared terms for age and number of fields of experience, too. The squared terms were never statistically significant at any conventional level. 
employed, because the size of this effect depends on both the value of the exogenous variable under consideration and on the values of all other variables in the model. A way to ease interpretation of the results is to compute the estimated probability of being a nascent entrepreneur for (hypothetical) individuals with different combinations of values of those exogenous variables that are at the center of interest. We follow this strategy: Based on the results reported in table II we consider a 40 years old male, and then compute the estimated probability for different combinations of the number of fields of experience and the number of professional degrees. ${ }^{9}$ Results of this exercise are reported in table III.

\section{[Table III near here]}

The estimated probabilities for being a nascent entrepreneur (which are rather similar for simulations based on the results for the unrestricted and the restricted sample) clearly demonstrate that both the number of fields of experience and the number of professional degrees do matter economically. To illustrate this, note that compared to a hypothetical person with no professional degree and only one field of experience a hypothetical person with three degrees and two fields of experience has an estimated probability of being a nascent entrepreneur that is three times as high (the results 2.4 percent compared to 7.3 percent, or 2.3 compared to 7.2 percent,

\footnotetext{
9 All computations were done using the setx and relogita ados that come with relogit; see fotnote 7 .
} 
when looking at the unrestricted and the restricted sample, respectively).

\section{Concluding remarks}

Using a different data set, a different definition of an entrepreneur, different ways to measure the extent of variety of professional experience, and a different econometric method compared to Wagner (2002), this paper leads to an identical conclusion: Lazear's jack-of-all-trades hypothesis of entrepreneurship is backed by German data, too. This supports the position that it should be considered as an important tool for economists in entrepreneurship research.

\section{References}

Bergmann, Heiko, Andrea Japsen and Christine Tamásy, 2002, Regionaler Entrepreneurship Monitor (REM). Gründungsaktivitäten und Rahmenbedingungen in zehn deutschen Regionen, Köln and Lüneburg: Universität zu Köln, Universität Lïneburg .

King, Gary and Langche Zeng, $2001 a$, 'Logistic Regression in Rare Events Data', Political Analysis 9 (2), 137-163.

King, Gary and Langche Zeng, 2001b, 'Explaining Rare Events in International Relations', International Organization 55 (3), $693-715$

Lazear, Edward P., 2002, 'Entrepreneurship', National Bureau of Economic Research Working Paper 9109, August. 
Reynolds, Paul D. et al., 2000, GEM Global Entrepreneurship Monitor. 2000 Executive Report, Kansas City: Kauffman Center for Entrepreneurial Leadership.

StataCorp (2003), Stata User's Guide, Release 8. College Station, TX: Stata Corporation.

Wagner, Joachim, 2002, 'Testing Lazear's Jack-of-All-Trades View of Entrepreneurship with German Micro Data', Institute for the Study of Labor IZA Discussion Paper 592, October (forthcoming in Applied Economics Letters). 
Table I

Descriptive statistics

Nascent entrepreneurs

Paid employees

A: Unrestricted sample

Sex (dummy; 1 = Male)

Age (years)

Number of fields of experience

Number of professional degrees

Number of cases

B: Restricted sample $e^{1}$

Sex (dummy; 1 = Male)

Age (years)

Number of fields of experience

Number of professional degrees

Number of cases

0.79

37.80

3.58

1.20
Std. Dev.

0.41

9.31

4.73

0.61

174

0.41

9.19

2.09

0.60

168
Mean Std. Dev.

0.610 .49

$40.28 \quad 10.33$

$3.27 \quad 2.61$

$1.08 \quad 0.53$

4808

1 The restricted sample is limited to persons with up to 13 reported fields of experience. 


\section{Table II}

Rare events logit estimates for being a nascent entrepreneur

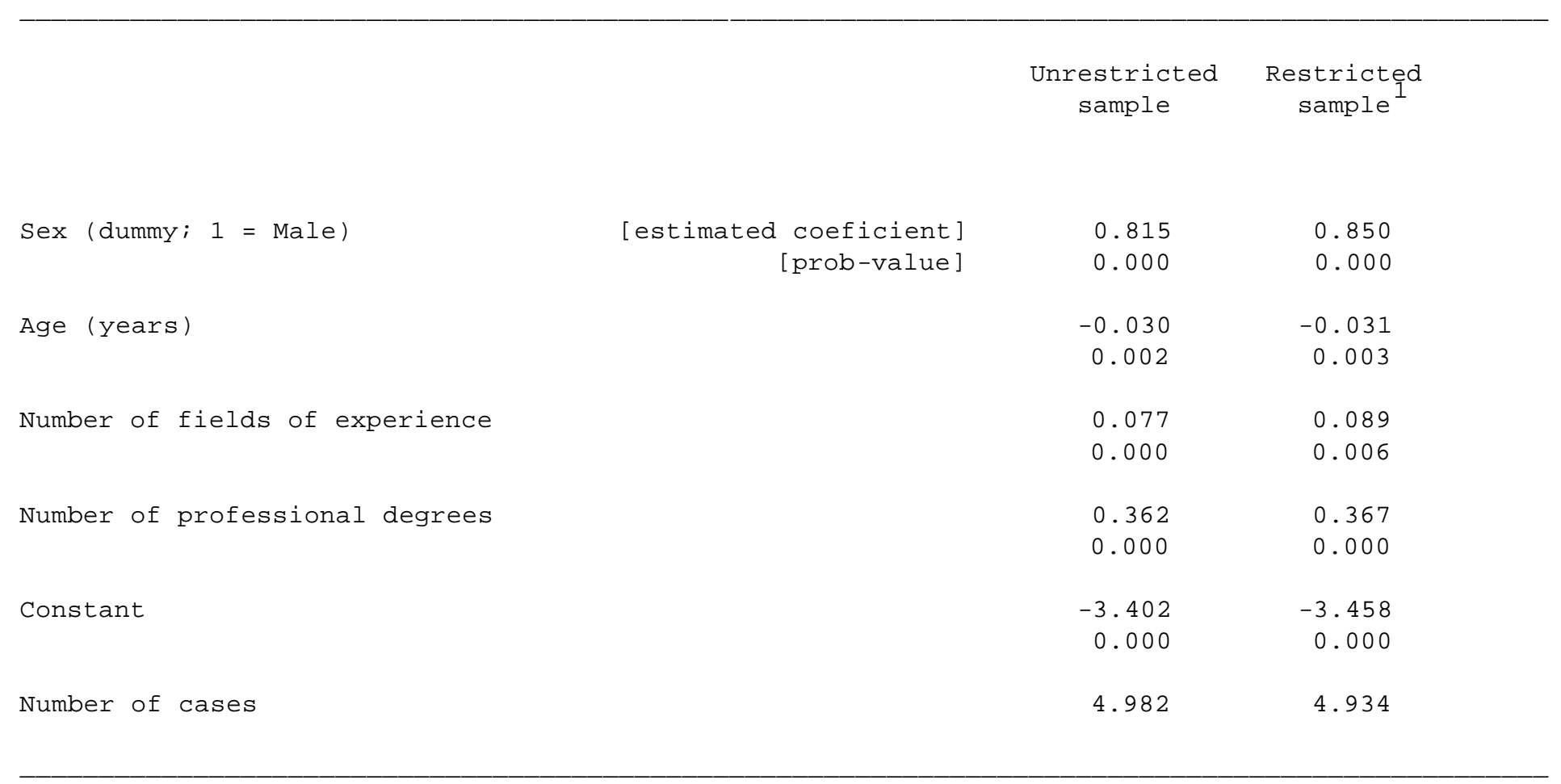

1 The restricted sample is limited to persons with up to 13 reported fields of experience. 
Table III

Estimated probability for being a nascent entrepreneur (percent) 1

Number of fields of experience

A: Unrestricted sample

\begin{tabular}{|c|c|c|c|c|c|c|c|c|c|c|c|}
\hline & & 1 & 2 & 3 & 4 & 5 & 6 & 7 & 8 & 9 & 10 \\
\hline & 2 & 4.8 & 5.2 & 5.5 & 6.0 & 6.4 & 6.9 & 7.5 & 8.0 & 8.5 & 9.2 \\
\hline
\end{tabular}

B: Restricted sample $e^{2}$

$\begin{array}{rrrrrrrrrrrrrrrr}\text { Number of professional degrees } & 0 & 2.3 & 2.5 & 2.8 & 3.0 & 3.3 & 3.6 & 3.9 & 4.3 & 4.6 & 5.1 \\ & 1 & 3.3 & 3.6 & 3.9 & 4.3 & 4.7 & 5.1 & 5.5 & 6.0 & 6.5 & 7.0 \\ & 2 & 4.7 & 5.1 & 5.6 & 6.0 & 6.5 & 7.1 & 7.8 & 8.5 & 9.0 & 10.0 \\ & 3 & 6.6 & 7.2 & 7.9 & 8.5 & 9.2 & 10.0 & 11.0 & 11.8 & 12.6 & 13.8\end{array}$

1 The estimates are based on the results reported in table II for a 40 years old male.

2 The restricted sample is limited to persons with up to 13 fields of experience. 


\section{IZA Discussion Papers}

\begin{tabular}{|c|c|c|c|c|}
\hline No. & Author(s) & Title & Area & Date \\
\hline 897 & $\begin{array}{l}\text { M. Brown } \\
\text { A. Falk } \\
\text { E. Fehr }\end{array}$ & $\begin{array}{l}\text { Relational Contracts and the Nature of Market } \\
\text { Interactions }\end{array}$ & 7 & $10 / 03$ \\
\hline 898 & $\begin{array}{l}\text { G. J. van den Berg } \\
\text { A. G. C. van Lomwel } \\
\text { J. C. van Ours }\end{array}$ & $\begin{array}{l}\text { Nonparametric Estimation of a Dependent } \\
\text { Competing Risks Model for Unemployment } \\
\text { Durations }\end{array}$ & 1 & $10 / 03$ \\
\hline 899 & $\begin{array}{l}\text { M. Karanassou } \\
\text { H. Sala } \\
\text { D. J. Snower }\end{array}$ & $\begin{array}{l}\text { Unemployment in the European Union: } \\
\text { Institutions, Prices, and Growth }\end{array}$ & 2 & $10 / 03$ \\
\hline 900 & $\begin{array}{l}\text { M. C. Berger } \\
\text { G. C. Blomquist } \\
\text { K. Sabirianova Peter }\end{array}$ & $\begin{array}{l}\text { Compensating Differentials in Emerging Labor } \\
\text { and Housing Markets: Estimates of Quality of } \\
\text { Life in Russian Cities }\end{array}$ & 4 & $10 / 03$ \\
\hline 901 & $\begin{array}{l}\text { P. F. Orazem } \\
\text { M. Vodopivec }\end{array}$ & $\begin{array}{l}\text { Do Market Pressures Induce Economic } \\
\text { Efficiency: The Case of Slovenian } \\
\text { Manufacturing, 1994-2001 }\end{array}$ & 4 & $10 / 03$ \\
\hline 902 & $\begin{array}{l}\text { P. Frijters } \\
\text { M. A. Shields } \\
\text { S. Wheatley Price }\end{array}$ & $\begin{array}{l}\text { Immigrant Job Search in the UK: Evidence from } \\
\text { Panel Data }\end{array}$ & 1 & $10 / 03$ \\
\hline 903 & $\begin{array}{l}\text { S. Girma } \\
\text { H. Görg }\end{array}$ & $\begin{array}{l}\text { Evaluating the Causal Effects of Foreign } \\
\text { Acquisition on Domestic Skilled and Unskilled } \\
\text { Wages }\end{array}$ & 2 & $10 / 03$ \\
\hline 904 & $\begin{array}{l}\text { S. P. Jenkins } \\
\text { P. Van Kerm }\end{array}$ & $\begin{array}{l}\text { Trends in Income Inequality, Pro-Poor Income } \\
\text { Growth and Income Mobility }\end{array}$ & 1 & $10 / 03$ \\
\hline 905 & $\begin{array}{l}\text { D. Weichselbaumer } \\
\text { R. Winter-Ebmer }\end{array}$ & $\begin{array}{l}\text { Rhetoric in Economic Research: The Case of } \\
\text { Gender Wage Differentials }\end{array}$ & 7 & $10 / 03$ \\
\hline 906 & $\begin{array}{l}\text { D. Weichselbaumer } \\
\text { R. Winter-Ebmer }\end{array}$ & $\begin{array}{l}\text { A Meta-Analysis of the International Gender } \\
\text { Wage Gap }\end{array}$ & 7 & $10 / 03$ \\
\hline 907 & $\begin{array}{l}\text { A. Dupuy } \\
\text { L. Borghans }\end{array}$ & $\begin{array}{l}\text { Supply and Demand, Allocation and Wage } \\
\text { Inequality: An International Comparison }\end{array}$ & 1 & $10 / 03$ \\
\hline 908 & M. Leonardi & Product Demand Shifts and Wage Inequality & 1 & $10 / 03$ \\
\hline 909 & M. Leonardi & $\begin{array}{l}\text { Firm Heterogeneity in Capital/Labor Ratios and } \\
\text { Wage Inequality }\end{array}$ & 1 & $10 / 03$ \\
\hline 910 & $\begin{array}{l}\text { P. Díaz-Vázquez } \\
\text { D. Snower }\end{array}$ & $\begin{array}{l}\text { On-the-Job Training, Firing Costs and } \\
\text { Employment }\end{array}$ & 5 & $10 / 03$ \\
\hline 911 & J. Wagner & $\begin{array}{l}\text { Are Nascent Entrepreneurs Jacks-of-All-Trades? } \\
\text { A Test of Lazear's Theory of Entrepreneurship } \\
\text { with German Data }\end{array}$ & 5 & $10 / 03$ \\
\hline
\end{tabular}

An updated list of IZA Discussion Papers is available on the center's homepage www.iza.org. 